\title{
Illegitimate recombination: An efficient method for random mutagenesis in Mycobacterium avium subsp. hominissuis
}

Faisal Asghar Khattak ${ }^{1,2}$, Ashutosh Kumar ${ }^{1,3}$, Elisabeth Kamal ${ }^{1}$, Ralph Kunisch ${ }^{1}$ and Astrid Lewin ${ }^{\text {* }}$

\begin{abstract}
Background: The genus Mycobacterium (M.) comprises highly pathogenic bacteria such as M. tuberculosis as well as environmental opportunistic bacteria called non-tuberculous mycobacteria (NTM). While the incidence of tuberculosis is declining in the developed world, infection rates by NTM are increasing. NTM are ubiquitous and have been isolated from soil, natural water sources, tap water, biofilms, aerosols, dust and sawdust. Lung infections as well as lymphadenitis are most often caused by M. avium subsp. hominissuis (MAH), which is considered to be among the clinically most important NTM. Only few virulence genes from M. avium have been defined among other things due to difficulties in generating M. avium mutants. More efforts in developing new methods for mutagenesis of M. avium and identification of virulence-associated genes are therefore needed.

Results: We developed a random mutagenesis method based on illegitimate recombination and integration of a Hygromycin-resistance marker. Screening for mutations possibly affecting virulence was performed by monitoring of $\mathrm{pH}$ resistance, colony morphology, cytokine induction in infected macrophages and intracellular persistence. Out of 50 randomly chosen Hygromycin-resistant colonies, four revealed to be affected in virulence-related traits. The mutated genes were MAV_4334 (nitroreductase family protein), MAV_5106 (phosphoenolpyruvate carboxykinase), MAV_1778 (GTP-binding protein LepA) and MAV_3128 (lysyl-tRNA synthetase LysS).
\end{abstract}

Conclusions: We established a random mutagenesis method for MAH that can be easily carried out and combined it with a set of phenotypic screening methods for the identification of virulence-associated mutants. By this method, four new MAH genes were identified that may be involved in virulence.

Keywords: Mycobacterium, Mycobacterium avium subsp. hominissuis, Non-tuberculous mycobacteria, Virulence, Mutagenesis, Illegitimate recombination

\section{Background}

The genus Mycobacterium (M.) comprises highly pathogenic bacteria such as $M$. tuberculosis as well as environmental opportunistic bacteria called NTM. They are ubiquitous and have been isolated from soil, natural water sources, tap water, biofilms, aerosols, dust and sawdust [1-3]. Remarkably, NTM are resistant to amoeba and protected against adverse conditions inside amoebal cysts [4]. While the incidence of tuberculosis is declining in the developed world, infection rates by NTM are increasing [5]. NTM cause skin infections,

\footnotetext{
*Correspondence: Lewina@rki.de

${ }^{1}$ Robert Koch-Institute, Division 16 Mycology/Parasitology/Intracellular

Pathogens, Nordufer 20, Berlin 13353, Germany

Full list of author information is available at the end of the article
}

lung diseases, lymphadenitis and disseminated disease mostly in immuno-compromised persons [5]. Lung infections as well as lymphadenitis are most often caused by $M$. avium [5,6], and $M$. avium is considered to be among the clinically most important NTM [7].

$M$. avium can be divided into four subspecies. $M$. avium subsp. paratuberculosis (MAP) causes the Johne's disease in ruminants; $M$. avium subsp. avium (MAA) and $M$. avium subsp. silvaticum infect birds; and finally M. avium subsp. hominissuis (MAH) which causes disease in humans [8].

The main route of infection in AIDS patients is the invasion of mucosal epithelial cells of the gastrointestinal tract, while in non-AIDS patients infections mainly occur through the respiratory route [9]. Recognition of 
M. avium by mouse macrophages involves binding of a $20-25 \mathrm{kDa}$ lipoprotein from the cell envelope of $M$. avium to TLR2. This interaction leads to bacteriostasis of $M$. avium in a MyD88-dependent way [10]. Even though the expression of TNF- $\alpha$ is also induced via TLR2-signalling, its role in growth restriction of $M$. avium is unclear [10]. IFN- $\gamma$ is considered to be a key cytokine for killing of $M$. avium and its expression is promoted by IL-18 secreted by $M$. avium-infected human macrophages [11]. Phagocytosis of M. avium is supposed to be mediated via binding of the bacteria to a variety of receptors including complement receptors CR1, CR2, CR3, CR4, the mannosyl-fucosyl-receptor, the fibronectin receptor, the integrin receptor $\alpha(v) \beta_{3}$, and the transferrin receptor [12-15]. M. avium inhibits the acidification of the phagosome and the fusion of the phagosome with lysosomes [16,17].

Intracellular $M$. avium survives antibacterial activities such as nitric oxide and reactive oxygen species and the mechanisms leading to killing of $M$. avium are still unknown [18]. The cell wall structure is an important factor determining virulence of $M$. avium [19]. Thus, different colony morphotypes (smooth opaque, smooth transparent, rough) distinguishable on Congo Red plates display different degrees of virulence. Smooth transparent and rough colonies are considered to be more virulent than smooth opaque colonies [20,21]. The colony morphotype is associated with the glycopeptidolipid (GPL) composition [19]. By inducing the release of various pro-inflammatory cytokines such as IL-1, IL-6 or TNF- $\alpha$, GPL modulate the immune response against mycobacteria [22].

Only relatively few virulence genes from MAH have been defined with respect to their role in infection. This is partly attributable to difficulties in generating $\mathrm{MAH}$ mutants. The major obstacle is the low transformation frequency if $\mathrm{MAH}$ is used as recipient. This also limits the efficiency of so far described random mutagenesis systems, such as the commercially available EZ$\mathrm{TN}<\mathrm{KAN} 2>$ Tnp Transposome from Epicentre. This Tn903-based system consists of a stable complex formed between the EZ::TN Transposase enzyme and the EZ:: $\mathrm{TN}<\mathrm{KAN}-2>$ Transposon. It was used in MAA and $\mathrm{MAH}$ to analyse mechanisms of multidrug resistance and the role of GPL [23-25]. Another system for the generation of random mutants is based on transduction using temperature-sensitive phages containing a transposon with a selection marker [26,27]. In other mycobacterial species such as $M$. tuberculosis and $M$. bovis BCG linear recombination substrates have been applied to generate random as well as site-directed mutants [28-30]. This approach, however, so far has not been published for mutagenesis of MAH or MAA. With the present study we intended to explore the performance of illegitimate recombination of a linear recombination substrate for random mutagenesis of MAH.

\section{Methods}

Bacterial strains, amoeba, cell lines and growth conditions Mycobacterial strains were grown in Middlebrook (MB) 7H9 broth (BD Biosciences, USA), supplemented with either 10\% ADC (BD Biosciences) or 10\% OADC (BD Biosciences) and $0.05 \%$ Tween 80 without shaking, and on $\mathrm{MB} 7 \mathrm{H} 11$ agar (BD Biosciences) at $37^{\circ} \mathrm{C}$. Escherichia coli DH5 $\alpha$ was used as host strain for plasmid pYUB854, a cosmid vector with a Hygromycin resistance ( $\mathrm{Hyg}^{\mathrm{r}}$ ) gene [31] and was cultured in/on Luria-Bertani broth and agar at $37^{\circ} \mathrm{C}$. Antibiotics when required were added at the following concentrations: Kanamycin $\left(50 \mu \mathrm{g} \mathrm{ml}^{-1}\right)$ or Hygromycin $\left(50 \mu \mathrm{g} \mathrm{ml}^{-1}\right)$. For Congo Red plating agar media was supplemented with $100 \mu \mathrm{g} \mathrm{ml}^{-1}$ Congo Red. The Acanthamoeba castellanii strain 1BU group II [32] was cultivated in PYG medium (Proteose peptone-Yeast extract-Glucose [33]) at $28^{\circ} \mathrm{C}$ and passaged once per week. The human macrophage cell line THP-1 (DSMZNo. ACC-16, DSMZ GmbH, Braunschweig, Germany) was maintained by passaging twice weekly in RPMI 1640 $\left(\right.$ GIBCO $^{\circledR}$ Invitrogen, Darmstadt, Germany) supplemented with $10 \%$ foetal bovine serum (Bio Whittaker, Walkersville, MD, USA). Cells were cultured in BD Falcon ${ }^{\mathrm{TM}}$ $75 \mathrm{~cm}^{2}$ trays (BD Biosciences) at $37^{\circ} \mathrm{C}$ and in $5 \% \mathrm{CO}_{2}$. For human macrophages infection and washing, Iscove's Modified Dulbecco's Media (IMDM) (PAA laboratories, Austria) with $3 \%$ Human AB-serum (PAA laboratories) was used.

\section{Molecular biology techniques}

All molecular biology techniques were carried out according to standard protocols [34] or according to the recommendations of the manufacturers of kits and enzymes. Primers were purchased from Metabion (Martinsried, Germany). Plasmid DNA was isolated with the QIAGEN Plasmid Mini Prep Kit (Qiagen, Hilden, Germany). Polymerase chain reaction (PCR) was performed with the DreamTaq Kit from Fermentas (St. Leon-Rot, Germany). Restriction enzymes were purchased from Fermentas. For elution of DNA fragments from agarose gels, the QIAquick Gel Extraction kit (Qiagen) was used. Ligation reactions were performed with the T4 DNA Ligase Kit from Fermentas. Genomic DNA from mycobacteria was isolated according to the protocol described in Sjöbring et al. [35]. Sequencing reactions were performed by using the Prism Big Dye FS Terminator Cycle Sequencing Ready Reaction Kit from PE Applied Biosystems (Darmstadt, Germany). Nucleotide sequence analysis was performed using the software packages MacVector ${ }^{\text {Ts }}$ 7.2.3 (Accelrys, Cambridge, UK) and Lasergene (DNASTAR, Inc., Madison, WI, USA). 
For Southern blotting $2 \mu \mathrm{g}$ of genomic DNA from Mycobacterium were digested with ApaI or SmaI, separated by electrophoresis in a $1 \%$ agarose gel and capillary transferred to positively charged nylon membranes (GE Healthcare, Buckinghamshire, UK) by following a standard protocol [34]. An 1818 bp region of the plasmid pYUB854 carrying the $\mathrm{Hyg}^{\mathrm{r}}$ gene was amplified using the primer pair Hyg2K FW (5'-CAC CGT ACG TCT CGA GGA ATT CCT G-3') and Hyg2K BW (5'-GCG TCG TGA AGA AGG TGT TGC TGA-3') and the digoxigenin labeling Kit (Roche, Mannheim Germany). The labeled PCR-product was used as a probe and detection was carried out using anti-digoxigenin-AP conjugate and CDP-star (Roche) according to the manufacturers' instructions.

Reverse PCR was applied to exactly locate the insertion sites of the $\mathrm{Hyg}^{\mathrm{r}}$ gene in the mutants. $2 \mu \mathrm{g}$ of DNA of each mutant was digested with the restriction enzyme ApaI or SmaI (which do not cut in the recombination substrate). The multiple sized DNA fragments were ethanol precipitated and then self-ligated by T4 DNA ligase enzyme, thus resulting in different sized circular DNA molecules. A PCR was then performed with primers [Hyg mut_1 (5' ${ }^{\prime}$ AAC TGG CGC AGT TCC TCT G-3') and Hyg mut_2 (5'-TCA GCA ACA CCT TCT TCA CGA-3')] binding within the $\mathrm{Hyg}^{\mathrm{r}}$ gene and oriented towards the unknown genomic MAH DNA located adjacent to the $\mathrm{Hgy}^{\mathrm{r}}$ gene. Sequencing of the PCR products using the primers Hyg mut_1 and Hyg mut_2 followed by BLAST analysis of the sequences allowed the exact identification of the insertion sites of the recombination substrates.

For quantitative RT-PCR the mutants were grown in $\mathrm{MB} / \mathrm{ADC}$ with $25 \mu \mathrm{g} \mathrm{ml}^{-1}$ of Hygromycin B to an $\mathrm{OD}_{600}$ of 2. The pellet of $10 \mathrm{ml}$ of culture was resuspended in $4 \mathrm{ml}$ of protoplasting buffer $(15 \mathrm{mM}$ of Tris- $\mathrm{HCl} \mathrm{pH} 8$, $0.45 \mathrm{M}$ of Sucrose, $8 \mathrm{mM}$ of EDTA) with $4 \mathrm{mg} \mathrm{ml}^{-1}$ Lysozyme. After incubation at $37^{\circ} \mathrm{C}$ for 45 minutes (min) the protoplasts were harvested by centrifugation and the pellets were resuspended in $1050 \mu \mathrm{l}$ of the RLT buffer from the RNeasy Minikit (Qiagen) with $10.5 \mu \mathrm{l}$ of $ß$-Mercaptoethanol. This suspension was transferred into tubes containing $25-50 \mathrm{mg}$ of glass beads $(0.5 \mathrm{~mm}$, PeqLab, Erlangen, Germany) and shaken in the homogenizer Precellys 24 (PeqLab) for $45 \mathrm{sec}$ at 6,500 g. The tubes were chilled on ice and centrifuged at 8,000 $\mathrm{g}$ for $5 \mathrm{~min}$ at $4^{\circ} \mathrm{C}$. Then, 0.7 volume of absolute Ethanol was added to the supernatant and this solution was distributed onto two columns of the RNeasy Kit. The samples were further processed as described in the RNeasy manual. Residual DNA present in the RNA preparations was removed with the Kit Desoxyribonuclease I (DNaseI) RNase free from Fermentas. The M-MLV Reverse Transcriptase and Random primers from Promega (WI, USA) were used to transcribe cDNA from the RNA. The cDNA was then used to perform real time PCR with the Maxima $^{\mathrm{TM}}$ SYBR Green/Rox qPCR Master Mix 2x from Fermentas. Primers were (i) for gene MAV_1779: 5'CTG CAG AAG AGC GTC TAC CC-3' and 5'-CTC TGT TCG GAG GTC GTC AT-3', (ii) for gene MAV_3129: 5'-GGT CAA GAC CAT CGA CGA CT-3' and 5'-AGA TCA TGA ACG GCA CAA CA-3', (iii) for gene MAV_4332: 5'-ATG GTC GAG CAG AGC ATC TGG-3' and 5'-ATG GCG TCC ACG AAC CG-3', (iv) for gene MAV_5105: 5'-GTT GTC GAG TTC ACC GGT CT-3' and 5'-ATT CAC TCG GCG AAT ACC TG-3' and (v) for 16S rRNA gene: $5^{\prime}$-GAG TGA GAA TGC AGG CAT GA-3' and 5'-ACA CGG GTA CGG GAA TAT CA-3'. The $\Delta \Delta \mathrm{C}_{\mathrm{T}}$ method was used to calculate the relative expression of the gene of interest in the mutant in comparison to the mean of its expression in the other three mutants. Normalisation was obtained by measuring the expression of $16 \mathrm{~S}$ rRNA gene as reference gene.

\section{Random mutagenesis by illegitimate recombination}

$1 \mu \mathrm{g}$ of plasmid pYUB854 DNA was double digested with restriction enzymes StuI and SpeI Fast digest at $37^{\circ} \mathrm{C}$ for $30 \mathrm{~min}$. The $2030 \mathrm{bp}$ linear DNA fragment carrying the $\mathrm{Hyg}^{\mathrm{r}}$ gene was gel-eluted after electrophoresis and 3-6 $\mu \mathrm{g}$ linear DNA fragment was transformed into $M$. avium strains by electroporation with the Biorad GenePulser apparatus applying $1000 \Omega, 25 \mu \mathrm{F}$ and $1.25 \mathrm{kV}$ in $1 \mathrm{~mm}$ gap cuvettes. The preparation of electrocompetent cells and electroporation were performed using standard protocols [36]. Plasmid pMN437 was used as positive control for transformation [37]. Electroporated bacteria were incubated at $37^{\circ} \mathrm{C}$ for 24 hours (h) before plating on selective plates. Potential mutants were characterised by PCR amplifying a part of the $\mathrm{Hyg}^{\mathrm{r}}$ gene [primers Hyg $2 \mathrm{~K} \mathrm{LC} \mathrm{FW} \mathrm{(5'-AGT} \mathrm{TCC}$ TCC GGA TCG GTG AA-3') and Hyg 2 K LC BW (5'-AGG TCG TCC CGG AAC TGC TGC G-3')], Southern blotting, reverse PCR (primers Hyg mut 1 and Hyg mut 2) and sequencing.

\section{Construction of a complemented derivative of mutant MAV 3128}

Primers MAV3128_MV306_1 (5'-CGG TCT AGA CTA TGC CTA CCT GCT CTC-3') and MAV3128_MV306_2 (5'-GCA GTT AAC CTA ATG CGG CTT GGC CAG$\left.3^{\prime}\right)$ were designed to amplify the gene MAV_3128 (3227 bp) plus $680 \mathrm{bp}$ of upstream sequence of the wild type with $p f u$ polymerase from Fermentas. The amplified product was cloned into the restriction sites $\mathrm{XbaI}$ and HpaI respectively of the integrative vector pMV306 [38]. The recombinant plasmid pFKaMAV3128 was transformed into $E$. coli $\mathrm{DH} 5 \alpha$ by a method already described 
by Hanahan [39]. The plasmid pFKaMAV3128 was then introduced into competent cells of mutant MAV_3128 by electroporation. PCR analyses with the primer pair MAV3128_MV306_1 and 2 confirmed the presence of wild type gene in the mutant MAV_3128.

\section{Screening for virulence-mutants Amoeba Plate Test (APT)}

The APT was previously described [40]. In short, known concentrations of Acanthamoeba castellanii (1BU group II strain) diluted in PYG medium were spread on MB agar plates and these plates served as test plates. For control plates only PYG medium without amoeba was spread on MB agar plates. Plates were dried and incubated at room temperature. The next day series of tenfold dilution $(1: 10,1: 100$, and 1:1000) in sterile water were prepared from cultures of the mutants and the $M$. avium 104 wild type (WT). $3 \mu \mathrm{l}$ of undiluted culture and of each dilution were spotted onto the test and control agar plates. Plates were then incubated at $30^{\circ} \mathrm{C}$ for one week. Mutants showing reduced growth on test plates compared to the control plates were selected for further molecular characterisation.

\section{Growth rate in broth cultures under $\mathrm{pH}$ stress}

The growth rates of mutants and WT were compared in MB 7H9 broth with neutral $\mathrm{pH}$ (7) and under $\mathrm{pH}$ stress $(\mathrm{pH} 5)$. Cultures were inoculated to an initial $\mathrm{OD}_{600}$ of 0.02 to 0.03 and allowed to grow for two weeks. Three cultures per strain were inoculated. Growth of cultures was determined by measurement of $\mathrm{OD}_{600}$ of cultures and also by quantification of ATP with the luminescence-based Kit BacTiter-Glo ${ }^{\mathrm{TM}}$ Microbial Cell Viability Assay (Promega). The luminescence was recorded as relative light units (RLU) with the microplate luminometer LB96V (EG \& G Berthold). Mutants showing differences of growth pattern compared to the WT in both neutral medium and under $\mathrm{pH}$ stress conditions were considered for further molecular characterisation.

\section{Congo Red plating}

$100 \mu \mathrm{l}$ of $1: 10^{5}$ and $1: 10^{6}$ dilutions in sterile water of mutants, complemented strain and WT were spread in triplicate on $\mathrm{MB}$ agar plates supplemented with OADC and $100 \mu \mathrm{g} \mathrm{ml}^{-1}$ Congo Red. Plates were incubated for 2-3 weeks and observed for colony morphology. Mutants showing differences in colony morphology (white vs. red staining, transparent vs. opaque colonies, smooth vs. rough colonies) compared to the WT were considered for further molecular characterisation.

\section{Induction of cytokine expression in THP-1 cells}

Infection of the cell line THP-1 was performed in 24-well cell culture plates (TPP) with three to five wells per sample. A total of 200,000 cells per well of THP-1 were grown along with addition of phorbol-12-myristate-13-acetate (PMA, Sigma, Taufkirchen, Germany) (10 $\left.\mathrm{ng} \mathrm{ml}^{-1}\right)$ and allowed to adhere to the surface of the plate well overnight at $37^{\circ} \mathrm{C}$ and in $5 \% \mathrm{CO}_{2}$. Cells were then infected with mutants and WT at a multiplicity of infection (MOI) of 50 colony forming units (CFU). The supernatants were removed after $24 \mathrm{~h}$ and cytokines were quantified in appropriate dilutions of the supernatants by ELISA using the Human ELISA Ready to go Kits (Natutec, Frankfurt, Germany).

\section{Intracellular survival in THP-1 cells}

THP-1 cells were seeded, treated with PMA and infected as described above. The supernatants were removed after $4 \mathrm{~h}$ infection period and adherent cells were washed twice with RPMI 1640. The cells were then treated with $200 \mathrm{mg} \mathrm{ml}^{-1}$ of Amikacin (Sigma) for $2 \mathrm{~h}$ to kill the mycobacteria in the supernatant. After washing twice with PBS buffer (10 mM sodium phosphate, $126 \mathrm{mM}$ sodium chloride, $\mathrm{pH}$ 7.2), $1 \mathrm{ml}$ of medium supplemented with $5 \mu \mathrm{g} \mathrm{ml}^{-1}$ of Amikacin was added to each well. Samples for quantification of intracellular bacteria were taken at the end of the infection time after removal and killing of extracellular bacteria and then after 1,2, and 4 days. For this, the cells were lysed in $1 \mathrm{ml}$ of water at $37^{\circ} \mathrm{C}$ for $20 \mathrm{~min}$ and the mycobacterial DNA in the lysates was quantified by realtime PCR as described in Lewin et al. [41]. Additionally, $100 \mu \mathrm{l}$ of $1: 10^{3}$ dilution in sterile water of samples were plated in triplicate on agar plates supplemented with ADC for counting of CFU.

\section{Intracellular survival in human monocytes}

Human monocytes were isolated from buffy coats from healthy donors using Ficoll-Paque ${ }^{\mathrm{TM}}$ Plus (GE Healthcare) and Percoll ${ }^{\mathrm{TM}}$ (GE Healthcare) gradient centrifugation according to the manufacturer's recommendations and as described in Sharbati et al. [42]. One million macrophages were seeded per well in 24-well cell culture plates, with three to five wells per sample per sampling point. Infection with mutants, complemented strain and WT, Amikacin treatment and sampling were done as described above for THP-1 cells infection, except that human monocytes were pre-activated with $100 \mathrm{U} \mathrm{ml}^{-1}$ of human IFN- $\gamma$ (Invitrogen, Darmstadt, Germany) and $10 \mathrm{ng} \mathrm{ml}^{-1}$ of LPS (Sigma), IMDM was used for washing, the MOI for infection was 10 and the dilution of the samples for plating and counting of CFU was 1:500.

\section{Results and discussion}

Generation and genetic characterisation of $M$. avium mutants

Our aims were the establishment of a new method to mutagenise MAH and the identification of mutants potentially affected in virulence. The mutagenesis approach 
involved transformation of a recombination substrate by electroporation into $\mathrm{MAH}$, and we therefore first identified clinical and environmental MAH strains applicable to electroporation. We considered a prior investigation of transformability to be necessary, because other authors had reported some clinical $M$. avium strains to be inaccessible to electroporation [43]. As proposed by Lee et al. [43], we chose a gfp-containing plasmid (pGFP: gfp cloned in vector pMV261 [38]) for transformation assays. We tested 14 clinical isolates and two soil isolates. Strain M. avium 104 was originally isolated from an HIV patient [44] and strains 2721/04, 10091/06, 10203/06, 4557/08, 4023/08, 3646/08, 3449/08, 3269/08, $2630 / 08,2014 / 08,772 / 08,709 / 08,528 / 08$ were isolated from children with lymphadenitis. Strains 128 and 129 are soil isolates. Out of these $16 \mathrm{M}$. avium strains, five (104, 2721/04, 2014/08, 4023/08 and 528/08) could be transformed with pGFP. As the genome sequence from $M$. avium strain 104 is available in the genome data bases, simplifying a precise mutant description, we decided to concentrate on this strain for further analysis.

Our mutagenesis approach took advantage of the high rate of illegitimate recombination in slow growing mycobacteria $[28,45]$ and their ability to take up linear DNA [29]. For selection purposes we chose the $\mathrm{Hyg}^{\mathrm{r}}$ gene instead of also often used Kanamycin resistance gene $\left(\mathrm{Km}^{\mathrm{r}}\right)$, because the $\mathrm{Hyg}^{\mathrm{r}}$ gene had been shown before to be superior to the $\mathrm{Km}^{\mathrm{r}}$ gene especially for the transformation of other than laboratory strains [46]. The $\mathrm{Hyg}^{\mathrm{r}}$ gene used for electroporation was flanked by plasmid DNA of $793 \mathrm{bp}$ on one side and $238 \mathrm{bp}$ on the other side. These flanking regions served as substrates for the illegitimate recombination. After electroporation of 3-6 $\mu \mathrm{g}$ of restriction fragment and selection on plates containing Hygromycin, about 1000 colonies could be obtained. Around ten percent of this number appeared on the negative control plates (no DNA added) and had to be considered spontaneously resistant. The positive controls (with 1-2 $\mu \mathrm{g}$ plasmid DNA) generated around 5-6 times more colonies than could be observed on the test plates. Transposon/transduction mutagenesis procedures have been reported to deliver around 1,000 to 3,500 mutants per mutagenesis procedure $[19,23,24,27,47,48]$ which means that the efficiency or our method was below the efficiency of transposon/transduction systems. Taking into account the simple handling of our method we consider it nevertheless to be a good alternative to the currently applied methods for mutagenesis of MAH.

Fifty randomly chosen colonies from the sample plates were tested for insertion of the $\mathrm{Hyg}^{\mathrm{r}}$ gene by performing a PCR using the primers Hyg $2 \mathrm{~K}$ LC FW and Hyg $2 \mathrm{~K}$ LC BW (data not shown). By this PCR 49 of the 50 colonies could be confirmed to carry an insertion of the
$\mathrm{Hyg}^{\mathrm{r}}$ gene in the genome. Additionally, Southern blots using a PCR fragment produced with primer pair Hyg2K FW and BW as probe were performed to verify if the insertions had occurred at different genome sites in different colonies (data not shown). Hybridising bands were obtained with the DNA from 20 colonies and confirmed independent insertion events.

Inverse-PCR using the primers Hyg mut 1 and Hyg mut 2 followed by sequencing of the PCR products enabled us to identify the sites of insertion of the $\mathrm{Hyg}^{\mathrm{r}}$ gene in 13 mutants. As shown in Figure 1, there were no hot spots for integration but the insertions were distributed within the whole $M$. avium genome.

The genetic characterisation of four virulenceassociated mutants is shown in Figure 2. The integration events were accompanied by deletions in all 13 mutants. The smallest deletion had a size of $2 \mathrm{bp}$, the largest one of $669 \mathrm{bp}$. All insertions were located within coding regions. Only in one mutant more than one gene was affected by the insertion. In 12 of the 13 mutants the linear recombination substrate had been completely inserted and in one mutant the inserted fragment had been shortened at both ends. The sequences next to the inserted fragment showed no special structure or nucleotide sequences.

Both, the random distribution of insertion sites and the low rate of large deletions affecting more than one gene are benefits of our method. Contrary to our experience with MAH, Collins and colleagues [49] observed more clustered insertions and deletions of up to 12

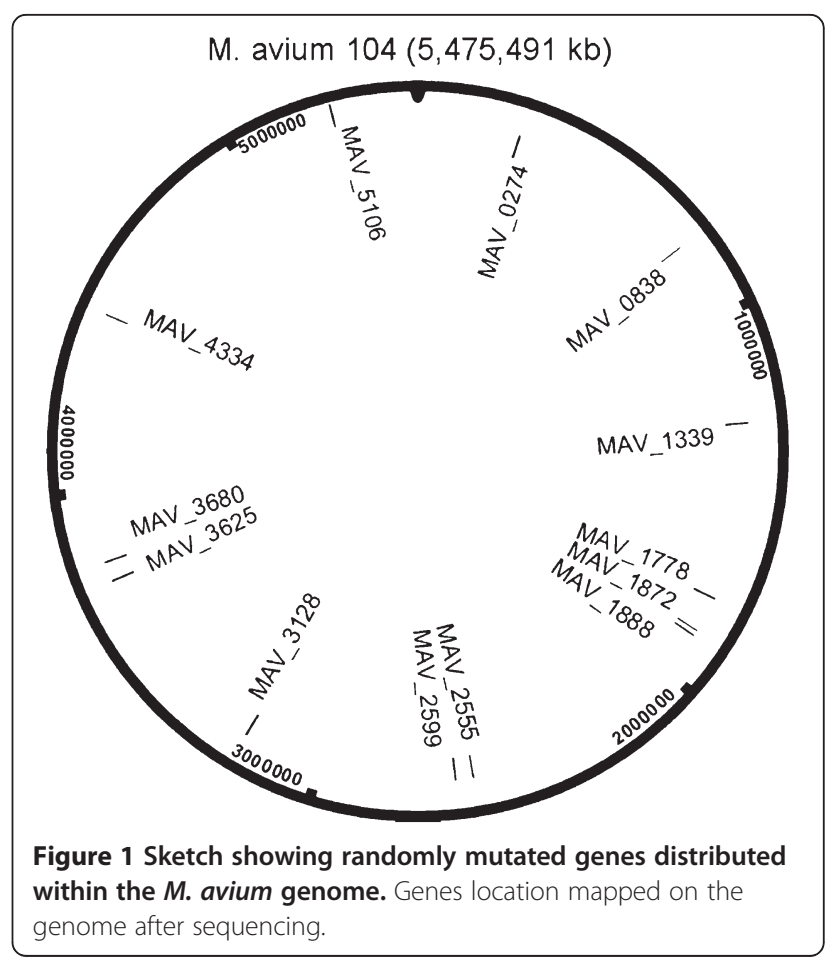




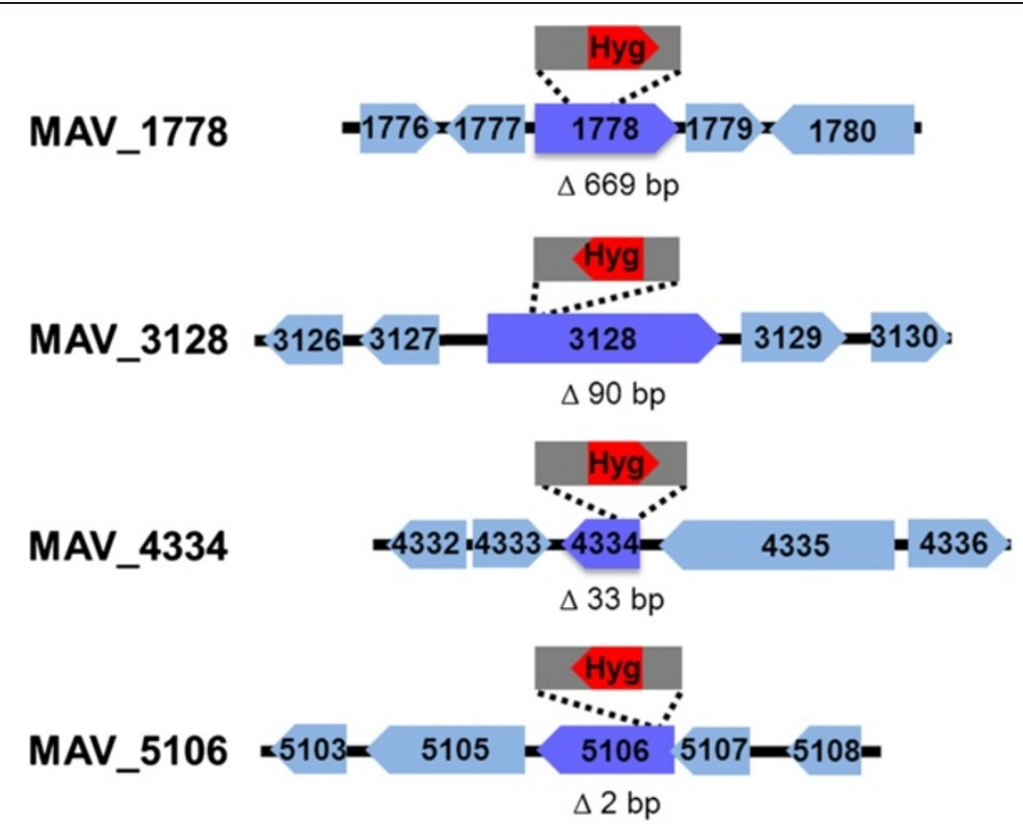

Figure 2 Sketch illustrating the genetic characterisation of the mutants MAV_1778, MAV_3128, MAV_4334, and MAV_5106. The sites of the insertion of the marker ( $\mathrm{Hyg}^{r}$ gene) were identified by inverse PCR followed by sequencing of the eluted PCR products. The figure shows for four mutants the mutated gene (dark blue) with the site of insertion of the fragment (grey) carrying the Hyg ${ }^{r}$ gene (red) and the four genes located upstream and downstream of the mutated gene (light blue). Numbers in the arrows indicate the gene names. The direction of the arrows stands for gene direction. Gene sizes and distances between genes are approximations. Below the map of each mutant the size of the deletion generated as result of insertion of the marker is indicated.

genes by mutagenising $M$. bovis with a DNA fragment carrying a Kanamycin resistance gene by illegitimate recombination. It would be interesting to find out the reasons for these differing outcomes. Are the specific parameters of the illegitimate recombination events species-specific or does the composition of the recombination substrate play a more important role?

In favor of a straight forward procedure, we concentrated our further efforts on those mutants, which fulfilled the following requirements: - an insertion in the middle of the coding region of a gene, - mutation of only one gene and - mutation of a single copy gene. After applying these criteria, eight mutants (see Table 1 for mutated genes and their functions) were selected for phenotypic analysis.

\section{Phenotypic characterisation of MAH mutants}

Since virulence is regulated on many different levels we applied more than one screening test (as for example intracellular multiplication) to identify a greater spectrum of relevant virulence-associated genes. We searched for phenotypic assays allowing a fast screening of our mutants and not requiring special and expensive equipment. The selected tests should monitor changes in (i) cell wall composition (plating on Congo Red Agar), (ii) resistance towards low $\mathrm{pH}$, (iii) amoeba resistance, (iv) induction of cytokine secretion by infected macrophages and (v) intracellular survival and growth in human macrophages.

Colony morphology and Congo Red staining characteristics The occurrence of different colony morphotypes is an eye-catching feature of $M$. avium including MAH and has attracted attention also because it is associated to virulence $[19,24,50,51]$. The colony morphology is influenced by the composition of the cell wall, which is a major determinant of mycobacterial virulence [52-54]. Congo Red, a planar hydrophobic molecule can bind to diverse lipids and lipoproteins and is thus applicable for the detection of changes in cell wall composition [54-56]. Upon plating of MAH on Congo Red agar plates, smooth

Table 1 Mutated $M$. avium genes and their functions

\begin{tabular}{ll}
\hline Mutated Gene & Function of the gene \\
\hline MAV_2555 & Short-chain dehydrogenase/reductase SDR \\
MAV_1888 & Hypothetical protein \\
MAV_4334 & Nitroreductase family protein \\
MAV_5106 & Phosphoenolpyruvate carboxykinase \\
MAV_1778 & GTP-Binding protein LepA \\
MAV_3128 & Lysl-tRNA synthetase (LysS) \\
MAV_3625 & Hypothetical protein \\
MAV_2599 & Hypothetical protein
\end{tabular}


transparent, smooth opaque and rough colonies as well as red and white colonies can be distinguished. Appearance of the three morphotypes smooth opaque, smooth transparent and rough was also confirmed for strain 104 [21]. While the opaque-transparent switch is reversible, the rough phenotype results from irreversible deletion of cell envelope glycopeptidolipid genes and is irreversible $[24,51]$.

TLC (Thin Layer Chromatography) analysis of the different morphotypes from strain 104 has been performed by Torelles [21]. They also analysed the sugar composition of the glycopeptidolipids (GPL) by gas chromatography-mass spectrometry (GC-MS) analysis. They found that the smooth opaque and smooth transparent colonies formed similar GPL and both expressed besides the nsGPL (ns: non-specific) the ssGPL (ss:serovar specific) of serovar 1 . However, the ssGPL was absent in the rough morphotype, which had a strong band of the nsGPL. A band in the lipopeptid region devoid of sugars was present in the smooth transparent morphotype and the rough morphotype but lacking in the smooth opaque morphotype. The sugar composition of all morphotypes showed the typical profiles related to ns and ssGPL of serovar 1 , only in the rough morphotype 6-deoxytalose and 3-O-methyl-6-deoxytalose were missing.

The transparent colony variant grows better in macrophages and animals compared to the opaque variant. Moreover, white transparent colonies survived better in macrophages than red transparent colonies $[19,24,50,51,56]$. These differences in intracellular survival may be caused by variations in the cytokine response towards infection by different morphotypes. The smooth opaque morphotype has been shown to induce higher levels of secretion of IL-1 $\alpha$, IL$1 \beta$ and TNF- $\alpha$ by human blood-derived monocytes compared to the smooth-transparent morphotype [57]. Variation in cytokine response upon infection with either smoothopaque or smooth-transparent $M$. avium was also reported upon infection of human microglia cultures [58].

The colony morphology of the WT and the mutants upon plating on Congo Red Agar is shown in Figure 3. The WT (Figure 3 A) mainly formed smooth-domedopaque (sdo) colonies along with smooth-transparent (st) colonies. Mutant MAV_2555 showed the same morphologies, but additionally smooth-flat-red (sfr) colonies were visible (Figure $3 \mathrm{~B}$ ). Relatively few smoothtransparent and rough colonies occurred in mutant MAV_1888 (Figure 3 C), MAV_4334 (Figure 3 D) and MAV_5106 (Figure 3 E). Mutant MAV_4334 (Figure 3 D) showed a higher variation with respect to the intensity of red color of smooth-domed-opaque colonies. Mutant MAV_1778 showed a very high degree of variability displaying red-rough (rr) and smooth-flat-red colonies additionally to the smooth-domed-opaque, smoothtransparent and rough-white (rw) colonies (Figure $3 \mathrm{~F}$ ).
The colonies generated by mutant MAV_3128 (Figure 3 $\mathrm{G})$ were in average larger in size and the smooth-opaque colonies appeared paler than in the WT. Also, the edges of these colonies were more irregular. Some red-rough colonies were also visible. The most multifaceted image was displayed by mutant MAV_3625. This strain generated smooth-domed-opaque, smooth-domed-red (sdr), smooth-flat-red, smooth-transparent and rough-transparent (rt) and red-rough colonies (Figure $3 \mathrm{H}$ ). A high proportion of red colonies (smooth-domed-red, smooth-flat-red, red-rough) was generated by mutant MAV_2599 (Figure 3 I) additionally to smooth-opaque and smooth-transparent colonies. This mutant produced only few rough (rough-transparent, rough-red) colonies. Altogether, we observed a high frequency and intensity of morphological changes in the mutants pointing to involvement of the mutated genes in the composition of cell wall structure. Since studies by different authors have related colony morphotype to virulence it would be of interest to investigate in further experiments if and to which degree the different colony types are stable and differ in their virulence.

\section{pH-resistance}

The intraphagosomal $\mathrm{pH}$ of $M$. avium-containing phagosomes decreases to $\mathrm{pH} 5.2$ in activated macrophages [59]. We therefore investigated the $\mathrm{pH}$-resistance of the mutants compared to the WT by inoculating them into $\mathrm{MB}$ broth at $\mathrm{pH} 5$ and $\mathrm{pH} 7$ and measuring the growth during 11 days at $37^{\circ} \mathrm{C}$ by means of OD measurement and ATP quantification. ATP measurement represents a much more sensitive method than the OD measurement. Additionally, the OD of a culture not only depends on cell number but also on the size of the cells, their morphology and the degree of clumping of the cells. For these reasons, ATP measurement was reported to be a more reliable method for quantification of mycobacteria in broth culture [41]. As shown in Figure 4, the WT grew better at neutral $\mathrm{pH}$ than at low $\mathrm{pH}$. After 11 days of growth in neutral medium, it generated 722,491 RLU (relative light units), while in medium with acidic pH only 143,082 RLU were achieved. The mutants MAV_2555, MAV_1888, MAV_4334 and MAV_5106 showed a similar growth pattern as the WT, both in neutral and acidic $\mathrm{pH}$ (data not shown). The mutants MAV_1778 and MAV_3128 grew similar as the WT at neutral $\mathrm{pH}$; however, at low $\mathrm{pH}$ these strains enhanced their growth rate even above the level reached at neutral $\mathrm{pH}$ (Figure $4 \mathrm{~A}$ and $\mathrm{B}$ ). While the mutant MAV_3128 showed enhanced growth in comparison to the WT at low pH already at day 1 , the mutant MAV_1778 showed an identical growth rate as the WT at low $\mathrm{pH}$ until day 5 and then showed strongly enhanced growth. The mutants MAV_3625 and MAV2599 grew better than the 

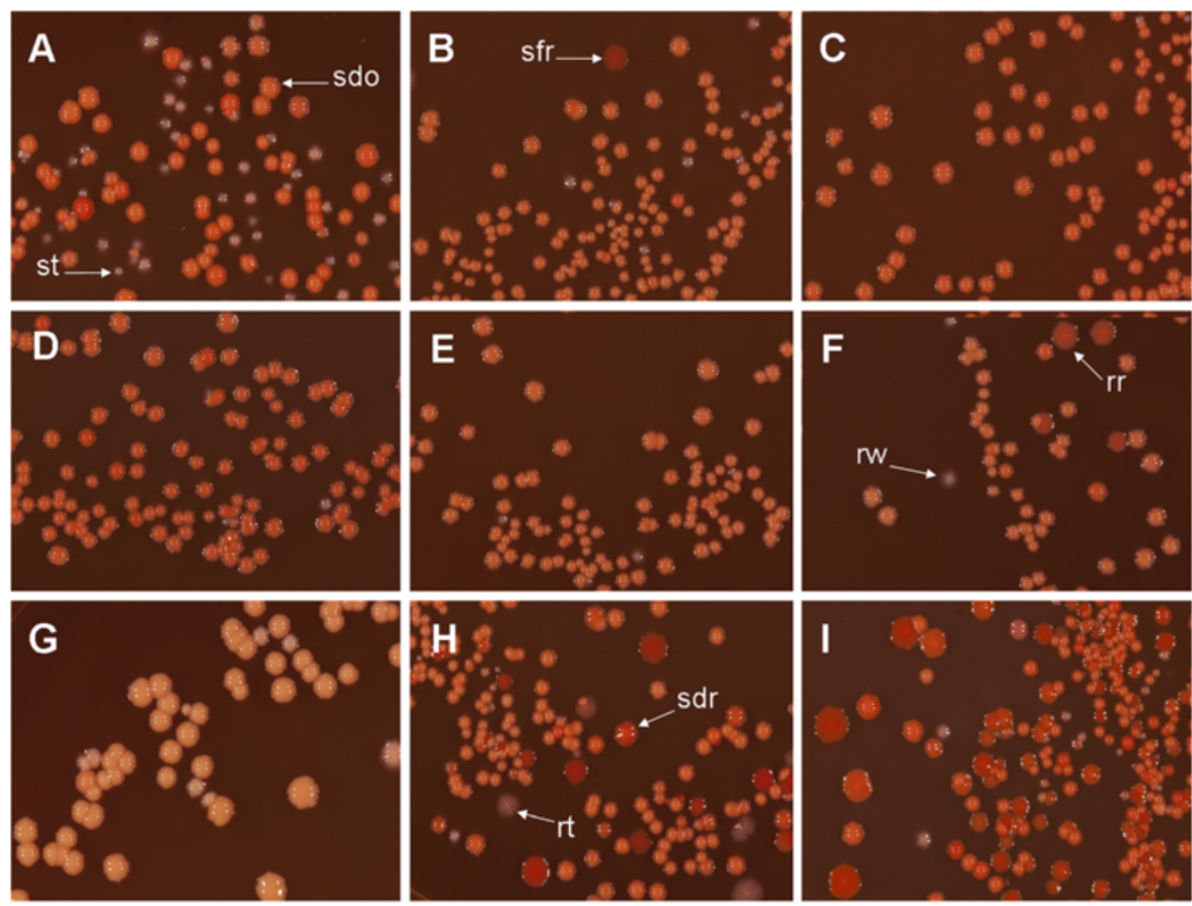

Figure 3 Colony morphology upon plating on Congo Red agar plates. Well-grown broth cultures of all strains were diluted 1:10 and 100 $\mu \mathrm{l}$ plated in triplicate onto Middlebrook agar with OADC containing $100 \mathrm{\mu g} \mathrm{m}^{-1}$ Congo Red. Plates were incubated on average for three weeks. The arrows point to smooth-domed-opaque (sdo), smooth-flat-red (sfr), smooth transparent (st), rough red (rr) and rough transparent (rt) colonies. A: WT; B: mutant MAV_2555; C: mutant MAV_1888; D: mutant MAV_4334; E: mutant MAV_5106; F: mutant MAV_1778; G: mutant MAV_3128; H: mutant MAV_3625; I: mutant MAV_2599.
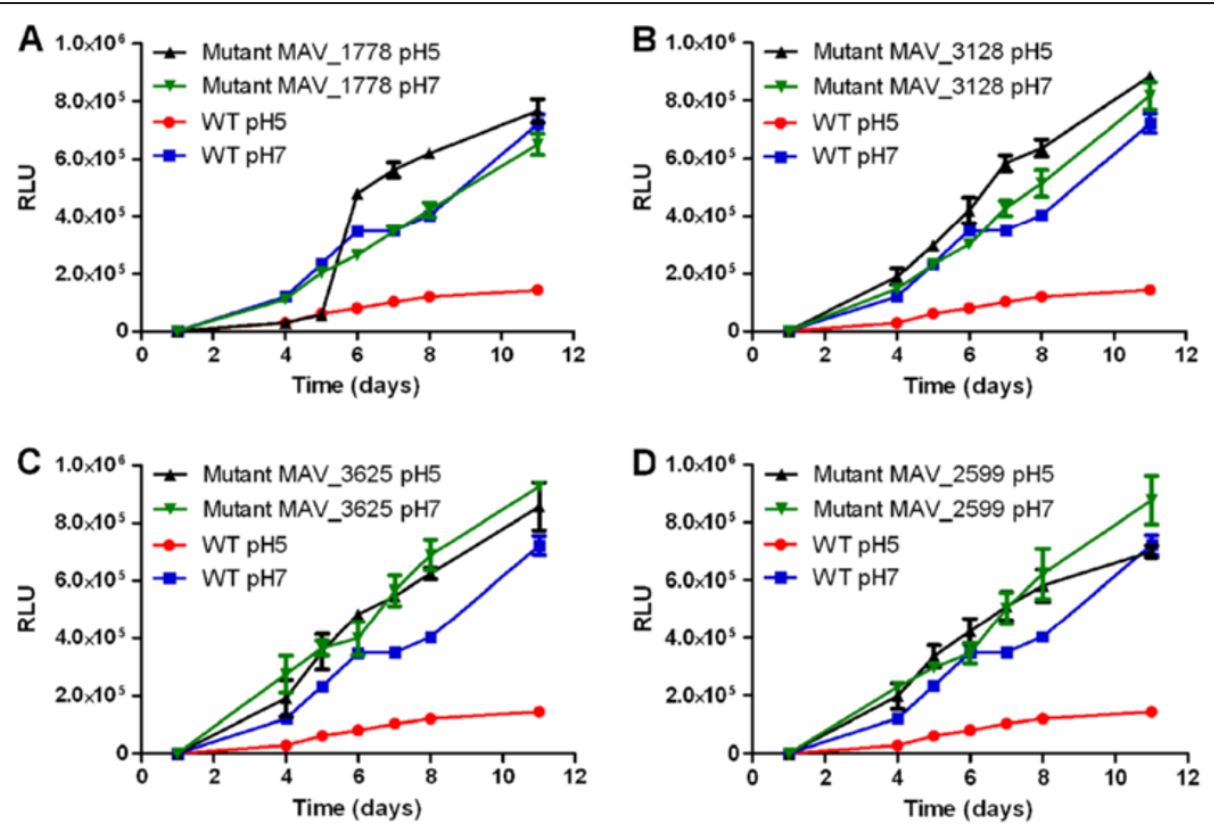

Figure 4 Resistance towards pH stress. The bacteria were grown in Middlebrook $7 \mathrm{H} 9$ broth with OADC at pH 7 and pH 5 during 11 days; the ATP content was recorded by quantification of the amount of ATP in the cultures. The amount of ATP is represented as RLU (relative light units). A: WT and mutant MAV_1778; B: WT and mutant MAV_3128; C: WT and mutant MAV_3625; D: WT and mutant MAV_2599. 
WT at $\mathrm{pH} 7$ and were able to maintain this growth rate at $\mathrm{pH} 5$ (Figure $4 \mathrm{C}$ and $\mathrm{D}$ ). In summary, the mutations either had no influence on the survival under $\mathrm{pH}$ stress conditions or improved resistance towards $\mathrm{pH}$ stress.

\section{Amoeba plating test}

Free-living amoebae are known to host environmental mycobacteria including $M$. avium, which are able to survive in Acanthamoeba trophozoites as well as in the exocysts [4,60,61]. Growth in Acanthamoeba was associated with subsequently enhanced virulence in infection experiments with mice [62]. Since some virulence mechanisms are employed by amoeba-resistant bacteria to survive in amoebae as well as in macrophages [4,63-65], amoebae have been used as test systems for determination of bacterial virulence factors $[40,63,66]$. An Acanthamoeba castellanii agar plate assay was developed and successfully employed for screening of mutants of Legionella pneumophila [40]. We adapted this APT to fit the growth conditions (medium, temperature, duration) of $M$. avium and tested the eight mutants in comparison to the WT. After incubation for five to seven days at $28^{\circ} \mathrm{C}$, the WT formed colonies even if the cultures were diluted $1: 10^{3}$ before being dropped on the lawn of amoebae. The growth of some mutants was more strongly affected by the amoebae but a differentiated evaluation of the impact of the various mutations on survival in the amoebae was not possible (data not shown). The APT thus was not sensitive enough to reveal differences in the capacity of the mutants to survive within the amoebae. This was surprising, because the APT has proven to be an efficient tool for the identification of virulence genes in L. pneumophilae [40]. There are several possible explanations for this discrepancy. Amoebae are the most important habitat of Legionella, while M. avium is not dependent on the presence of amoebae for survival and distribution. As a consequence, Legionella might have evolved more important virulence factors interacting with amoebae. Another possible explanation may result from the differences in the generation times of L. pneumophilae and M. avium. L. pneumophilae is a fast-growing bacterium forming clearly visible colonies few days after plating, while the slow-growing $M$. avium 104 requires two weeks to generate colonies of comparable size. This time span may be too long to maintain the amoebae as trophozoites actively interacting with the mycobacteria. In conclusion, we estimate the APT to be of only little value for the detection of virulence genes of slow-growing mycobacteria.

\section{Induction of cytokine secretion}

The innate immune recognition by phagocytic cells mediates cellular activation enabling killing of the bacteria and the production of pro- and anti-inflammatory cytokines.
The signaling cascade is mainly initiated by binding of $M$. avium components to TLR2 followed by recruitment of the MyD88 adaptor molecule and the activation of NFkB and MAP kinases. This chain of events ends with the induction of inflammatory cytokines [10] controlling macrophage activation and granuloma formation. We monitored the induction of cytokine expression of THP-1 macrophages by the WT and the mutants in order to evaluate their ability to stimulate the immune signaling. To this aim we quantified the secretion of selected cytokines: the pro-inflammatory cytokines TNF- $\alpha$, IL-1 $\beta$ and the antiinflammatory cytokine IL-10. Five independent experiments were normalised for WT (expression ratio 1) to determine the expression ratio for the mutants in comparison to WT. While results for TNF- $\alpha$ and IL- $1 \beta$ were not significantly different as compared to WT, IL-10 was significantly (P $<0.007$ ) up-regulated for mutant MAV_4334 (Figure 5). IL10 can inhibit the production of inflammatory cytokines such as TNF- $\alpha$ in monocytes pre-activated by IFN- $\gamma$ and LPS $[67,68]$ and therefore plays an important role in the immune response.

\section{Intracellular survival}

The ability to survive and even replicate inside the phagosomes of macrophages is an important virulence factor of mycobacteria and was therefore included in our screening options. Infection experiments with macrophages give information on the early host response to mycobacterial infections [69]. Different types of macrophages or monocytic cells have been employed to assess mycobacterial virulence and among these the human macrophage-like cell line THP-1 has proven a suitable

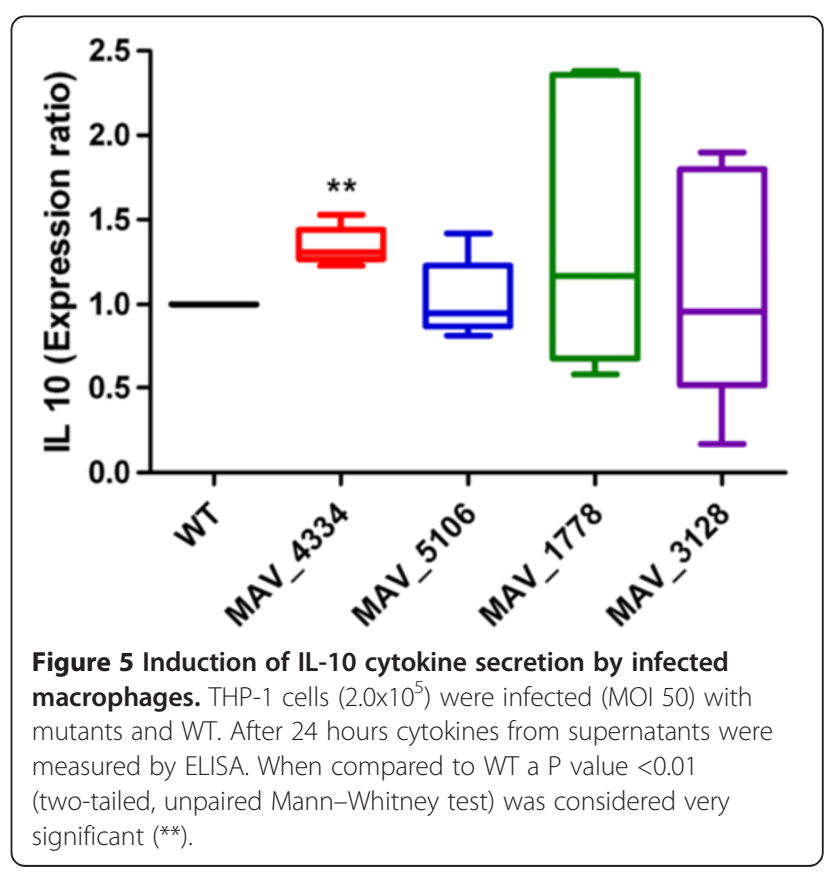


system for virulence testing $[69,70]$. It was shown that THP-1 cells are similar to primary human monocytederived macrophages with respect to their ability to take up mycobacteria and limit their growth [71]. We infected THP-1 cells that had been differentiated by PMA with the WT and the mutants. Intracellular mycobacteria were measured by quantitative real-time PCR and CFU by plating. Survival of mutants in THP-1 cells was not consistently different if compared to the WT (data not shown). More significant differences were obtained when using human blood monocytes for the infection experiments. The growth of mutant MAV_4334, MAV_1778 and MAV_3128 was affected the most in human monocytes (Figure 6). They were reduced significantly for the first two days $(\mathrm{P}<0.05$ to $\mathrm{P}<0.01)$. Mutant MAV_4334 and MAV_1778 (Figure $6 \mathrm{~A}$ and C) were almost reduced to half during the first two days. As shown in Figure 6 D, mutant MAV_3128 had the highest significant $(\mathrm{P}<0.001)$ difference in growth as compared to WT, which had survived better during this time period. The mutant MAV_5106 largely differed from other mutants and during four days of infection had shown constant survival (Figure $6 \mathrm{~B}$ ). The capacity of mutant
MAV_5106 to survive better in macrophages suggests that it may be characterised by a higher virulence as compared to the other mutants. Tateish et al. [70] compared the virulence of different $M$. avium isolates in humans, immuno-competent mice and THP-1 cells. They found that the strain causing the most serious disease in humans and the highest bacterial load in mouse lungs also grew better in THP-1 cells than the other strains tested. According to this, the mutants MAV_4334, MAV_1778 and MAV_3128 may display reduced virulence and the corresponding genes may represent virulence-associated genes.

\section{Evaluation of the screening procedure}

We have employed five screening methods (colony morphology, $\mathrm{pH}$ stress resistance, amoeba resistance, cytokine induction, intracellular survival) to select mutants affected in virulence-related traits. Two mutants (MAV_4334 and MAV_3128) responded differently from the WT in four of these five screening tests and two mutants (MAV_5106 and MAV_1778) reacted differently in three screening tests. The most prominent differences were exhibited by mutant MAV_3128. The other mutants either did not show any
A

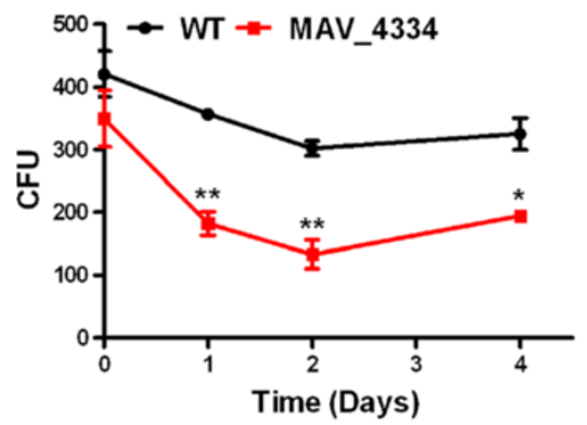

C

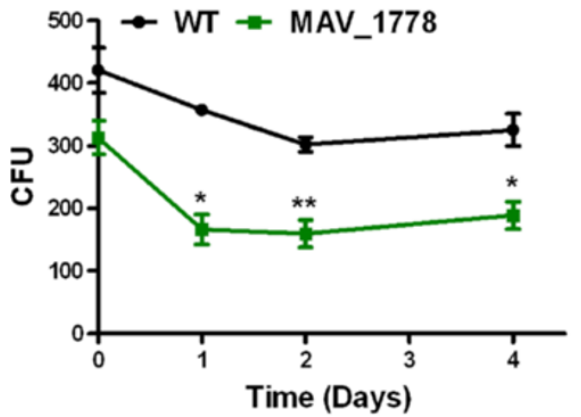

B

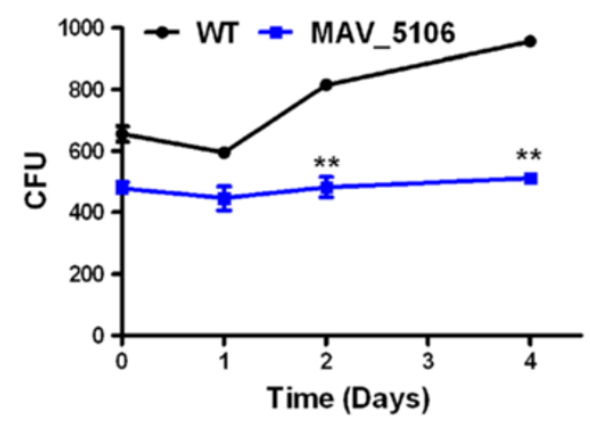

D

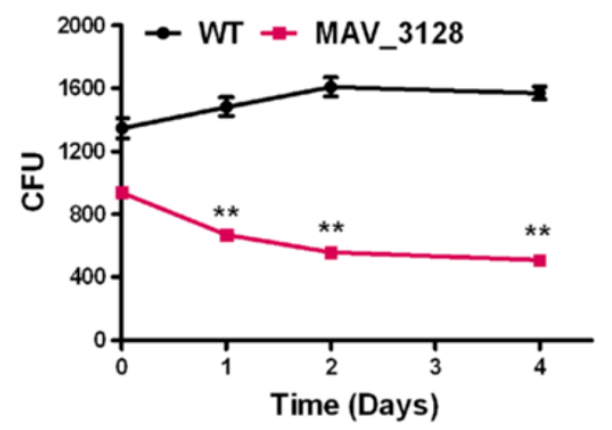

Figure 6 Intracellular survival of mutants compared to WT in human monocytes. Human blood monocytes $\left(1.0 \times 10^{6}\right)$ from healthy volunteers were infected (MOI 10) with mutants and WT. Intracellular bacteria were quantified after 4 hour of infection, and after 1, 2, \& 4 days. The monocytes were lysed in $1 \mathrm{ml}$ of sterile water and $100 \mu \mathrm{l}$ of 1:500 dilution in sterile water of sample were plated on Middlebrook agar plates supplemented with ADC for CFU counting. A: WT and mutant MAV_4334; B: WT and mutant MAV_5106; C: WT and mutant MAV_1778; D: WT and mutant MAV_3128. Statistical analysis was done using a two tailed, paired Student's $t$ test. When compared to wild-type a $\mathrm{P}<0.05$ was considered significant $(*)$ and a $P<0.01$ very significant $(* *)$. 
differences compared to the WT or reacted differently in only one or two tests.

The insertions in mutants MAV_4334, MAV_5106, MAV_1778 and MAV_3128 have been mapped and the structure of the mutated regions has been analyzed on nucleotide level. In all cases only one gene has been mutagenised. The insertions are located in the genes MAV_4334 (nitrogenase reductase family), MAV_5106 (phosphoenolpyruvate carboxykinase), MAV_1778 (GTPbinding protein LepA) and MAV_3128 (lysyl-tRNA synthestase LysS).

Phosphoenolpyruvate carboxykinases (PEPCK) catalyse the reversible decarboxylation and phosphorylation of oxaloacetate to form phosphoenolpyruvate. Mutations of the PEPCK gene from $M$. bovis BCG are characterised by attenuated virulence and reduced survival in macrophages [72]. The PEPCK gene from M. tuberculosis was shown to be required for replication in murine bone marrow macrophages and mice [73].

The LepA protein from $M$. tuberculosis possess GTPase activity. Bacterial GTP-binding proteins play a role in regulation of ribosomal function and cell cycle, modulation of DNA partitioning and DNA segregation [74]. In Helicobacter pylori LepA is important for growth at low $\mathrm{pH}$ and may play a role in infection [75].
The lysS gene from $M$. avium is $81 \%$ homologous to the lys $X$ gene from M. tuberculosis. LysX from M. tuberculosis is required for synthesis of lysinylated phosphatidylglycerol. A LysX mutant was shown to be sensitive to cationic antibiotics and peptides, to be more lysosomeassociated and to display defective growth in mouse and guinea pig lungs [76].

So far, nothing is known about the role of the nitrogenase reductase family protein for growth and pathogenicity of mycobacteria and answering this question will be one of our future aims.

In summary, by analysing 50 random mutants, we uncovered four genes from MAH to play a role in the interaction with host cells and thus in virulence. The homologues of three of the four genes were shown to contribute to virulence in other bacterial species, which supports the significance of our screening procedure.

\section{Mutant complementation and evaluation of polar down-stream effects}

To prove that the phenotypes of the mutants were indeed a cause of the inactivation of the mutated genes, we aimed at complementing the mutants by introducing the intact genes by electroporation. Only the transfer of gene MAV_3128 into the respective mutant was
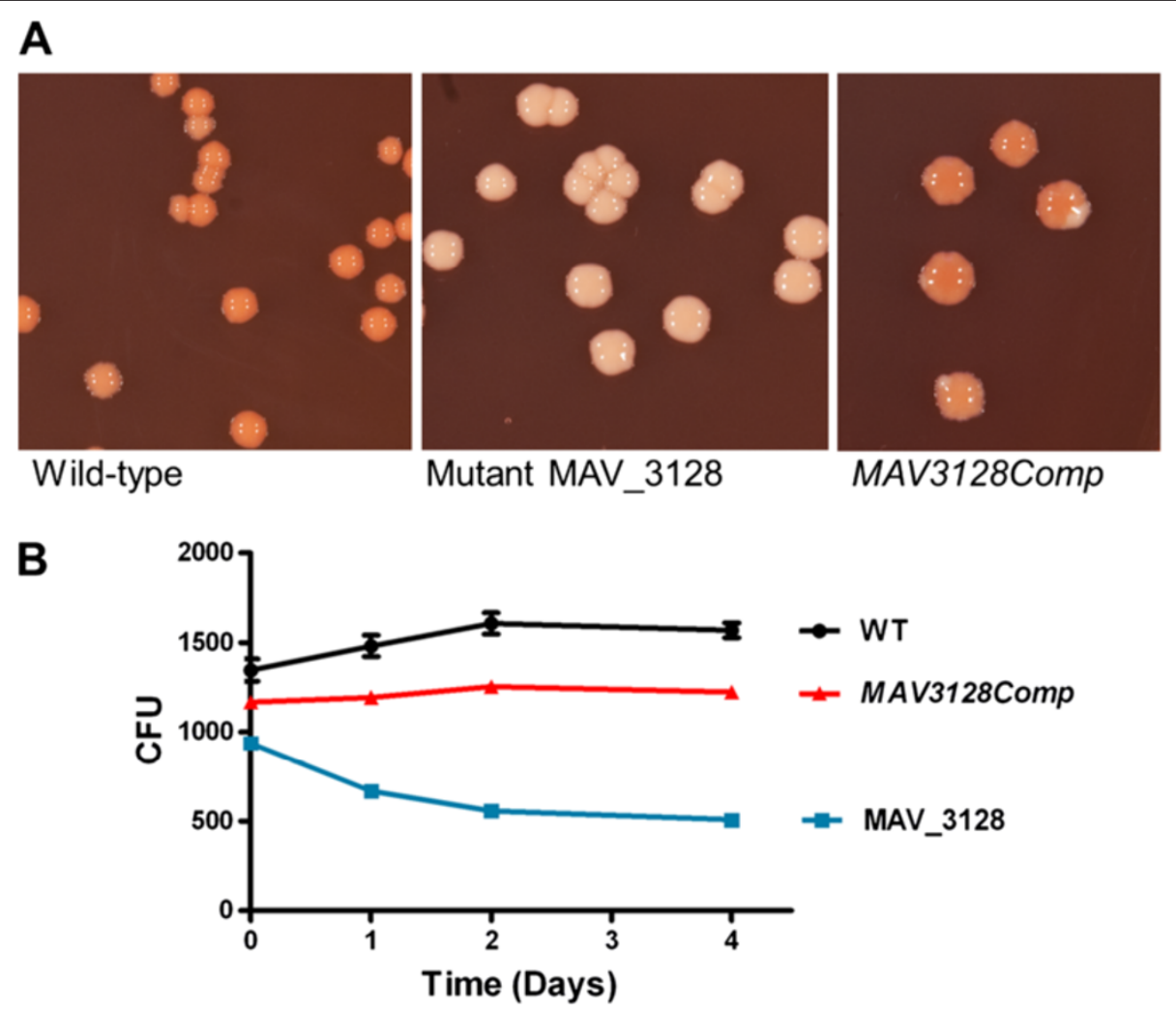

Figure 7 Phenotype of the complemented strain MAV3128Comp compared to mutant MAV_3128 and WT. A: Colony morphology on Congo Red plates. B: Intracellular survival in human blood monocytes. 
successful. Mutant MAV_3128 had shown the strongest and most different phenotypic changes in comparison to wild-type among the eight tested mutants in almost all the phenotypic tests. A complementation is best performed if the copy number of gene transcripts generated by the complementing gene narrows the copy number in the wild-type. We therefore used a plasmid for cloning (pMV306) that integrates once in the genome of the mutant and included the upstream region of $M A V_{-} 3128$ to most likely cover the promoter of the gene. This upstream region had a size of about $680 \mathrm{bp}$ and the gene $M A V_{-} 3127$, which is located upstream of $M A V_{-} 3128$, has an orientation in opposite direction of $M A V_{-} 3128$ (see Figure 2). Therefore it was expected that the upstream region will contain the promoter sequence of the MAV_3128 gene. Thus a 3907 bp DNA fragment was cloned into the integrative vector pMV306. The resulting recombinant plasmid pFKaMAV3128 was successfully transformed into the mutant MAV_3128 to generate the complemented strain MAV3128Comp.

Selected phenotypic tests (plating on Congo Red Agar and intracellular survival) were repeated with the complemented strain. Upon plating on Congo Red agar (Figure 7 A), the pale colour of mutant MAV_3128 could no longer be seen in MAV3128Comp, except some pale corners in colonies. This may indicate the loss of the plasmid in absence of selection pressure. The intracellular survival experiment has also conclusively indicated a reversal of the mutation. The complemented strain showed more similar growth tendency towards wild-type strain than towards the mutant (Figure 7 B). In conclusion we successfully complemented the mutant MAV_3128 by introducing the intact gene proving that the phenotype of mutant MAV_3128 was indeed caused by the inactivation of gene $M A V \_3128$ and not by a second line mutation.

Since introduction of the intact genes into the other three mutants failed we additionally investigated the occurrence of polar effects in the four mutants by quantitative RT-PCR. As polar effects most probably will have an impact on genes which are located downstream of the mutated gene and exhibit the same orientation, we quantified expression of genes $M A V_{-} 1779$ (in mutant MAV_1778), MAV_3129 (in mutant MAV_3128), $M A V \_4332$ (in mutant MAV_4334) and MAV_5105 (in mutant MAV_5106) by qRT-PCR. The $16 \mathrm{~S}$ rRNA gene was used as reference gene. The $\Delta \Delta C_{T}$ method was used to calculate expression of the gene in the corresponding mutant compared to the mean expression in the other three mutants. The expression levels measured were: $M A V \_1779$ (in mutant MAV_1778): 2.1 fold, $M A V \_3129$ (in mutant MAV_3128): 1.1 fold, $M A V \_4332$ (in mutant MAV_4334): 1.0 fold and MAV_5105 (in mutant MAV_5106): 1.4 fold. In three of the four mutants, the expression of the down-stream genes transcribed in the same direction was not or only slightly changed. Only in mutant MAV_1778 a two-fold expression of gene $M A V_{-} 1779$ was observed. We conclude that with one exception no relevant polar effects could be observed.

\section{Conclusions}

Our study proposes a well-functioning method to randomly mutagenise $\mathrm{MAH}$, by illegitimate recombination, genetically characterise the mutations to the nucleotide level and screen the mutants with simple phenotypic tests providing information about virulence-associated features.

\section{Competing interests}

The authors declare that they have no competing interests.

\section{Authors' contributions}

Conceived and designed the study: FAK and AL. Carried out the Laboratory work: FAK, AK, EK and RK. Manuscript drafted: FAK and AL. All authors read and approved the final manuscript.

\section{Acknowledgements}

We thank Dr. Elvira Richter, from National Reference Center for Mycobacteria, Borstel, Germany for generously providing $14 \mathrm{M}$. avium clinical isolates and Dr. Petra Möbius, from Friedrich Löffler Institute, Jena, Germany for giving 2 M. avium environmental strains. We also thank Prof. Dr. Michael Niederweis, University of Alabama, Birmingham, USA for donating plasmid pMN437.

\section{Author details}

${ }^{1}$ Robert Koch-Institute, Division 16 Mycology/Parasitology/Intracellular Pathogens, Nordufer 20, Berlin 13353, Germany. ${ }^{2}$ Faculty of Biological Sciences, Islamia College Peshawar (a public sector University),

KhyberPakhtunkhwa, Pakistan. ${ }^{3}$ Pathogen Biology Laboratory, Department of Biotechnology, School of Life Sciences, Unversity of Hyderabad, Hyderabad, India.

Received: 17 August 2012 Accepted: 7 September 2012 Published: 11 September 2012

\section{References}

1. Kirschner RA Jr, Parker BC, Falkinham III JO: Epidemiology of infection by nontuberculous mycobacteria: Mycobacterium avium, Mycobacterium intracellulare, and Mycobacterium scrofulaceum in acid, brown-water swamps of the Southeastern United States and their association with environmental variables. Am Rev Respir Dis 1992, 145:271-275.

2. Matlova L, Dvorska L, Palecek K, Maurenc L, Bartos M, Pavlik I: Impact of sawdust and wood shavings in bedding on pig tuberculous lesions in lymph nodes, and IS1245 RFLP analysis of Mycobacterium avium subsp. hominissuis of serotypes 6 and 8 isolated from pigs and environment. Vet Microbiol 2004, 102:227-236.

3. van Ingen J, Boeree MJ, Dekhuijzen PNR, van Soolingen D: Environmental sources of rapid growing nontuberculous mycobacteria causing disease in humans. Clin Microbiol Infect 2009, 15:888-893.

4. Salah IB, Ghigo E, Drancourt M: Free-living amoebae, a training field for macrophage resistance of mycobacteria. Clin Microbiol Infect 2009, 15:894-905.

5. McGrath EE, McCabe J, Anderson PB: Guidelines on the diagnosis and treatment of pulmonary non-tuberculous mycobacteria infection. Int J Clin Pract 2008, 62:1947-1955.

6. Cassidy PM, Hedberg K, Saulson A, McNelly E, Winthrop KL: Nontuberculous mycobacterial disease prevalence and risk factors: A changing epidemiology. Clin Infect Dis 2009, 49:e124-e129.

7. Alvarez-Uria G: Lung disease caused by nontuberculous mycobacteria. Current Opinion in Pulmonary Medicine 2010, 16:251-256.

8. Mijs W, de Haas P, Rossau R, Van Der Laan T, Rigouts L, Portaels F, van Soolingen D: Molecular evidence to support a proposal to reserve the designation Mycobacterium avium subsp. avium for bird-type isolates 
and 'M. avium subsp. hominissuis' for the human/porcine type of $\mathrm{M}$. avium. Int J Syst Evol Microbiol 2002, 52:1505-1518.

9. Harriff MJ, Danelishvili L, Wu M, Wilder C, McNamara M, Kent ML, Bermudez LE: Mycobacterium avium genes MAV-5138 and MAV-3679 are transcriptional regulators that play a role in invasion of epithelial cells, in part by their regulation of CipA, a putative surface protein interacting with host cell signaling pathways. J Bacteriol 2009, 191:1132-1142.

10. Salomé Gomes M, Fernandes SS, Cordeiro JV, Gomes SS, Vieira A, Appelberg $R$ : Engagement of Toll-like receptor 2 in mouse macrophages infected with Mycobacterium avium induces non-oxidative and TNF-independent anti-mycobacterial activity. Eur J Immunol 2008, 38:2180-2189.

11. Shiratsuchi H, Ellner JJ: Expression of IL-18 by Mycobacterium aviuminfected human monocytes; association with M. avium virulence. Clin Exp Immunol 2001, 123:203-209.

12. Bermudez LE, Young LS, Enkel H: Interaction of Mycobacterium avium complex with human macrophages: Roles of membrane receptors and serum proteins. Infect Immun 1991, 59:1697-1702.

13. Rao SP, Ogata K, Catanzaro A: Mycobacterium avium-M. intracellulare binds to the integrin receptor alpha $v$ beta 3 on human monocytes and monocyte-derived macrophages. Infect Immun 1993, 61:663-670.

14. Roecklein JA, Swartz RP, Yeager H Jr: Nonopsonic uptake of Mycobacterium avium complex by human monocytes and alveolar macrophages. Journal of Laboratory and Clinical Medicine 1992, 119:772-781.

15. Jha S, Danelishvili L, Wagner D, Maser J, Li Y, Moric I, Vogt S, Yamazaki Y, Lai B, Bermudez L: Virulence-related Mycobacterium avium MAV_2928 gene is associated with vacuole remodeling in macrophages. BMC Microbiol 2010, 10:100.

16. De Chastellier C, Lang T, Thilo L: Phagocytic processing of the macrophage endoparasite, Mycobacterium avium, in comparison to phagosomes which contain Bacillus subtilis or latex beads. European Journal of Cell Biology 1995, 68:167-182.

17. Oh YK, Straubinger RM: Intracellular fate of Mycobacterium avium: Use of dual-label spectrofluorometry to investigate the influence of bacterial viability opsonization on phagosomal $\mathrm{pH}$ phagosome-lysosome interaction. Infect Immun 1996, 64:319-325.

18. Li YJ, Danelishvili L, Wagner D, Petrofsky M, Bermudez LE: Identification of virulence determinants of Mycobacterium avium that impact on the ability to resist host killing mechanisms. J Med Microbio/ 2010, 59:8-16.

19. Laurent JP, Hauge K, Burnside K, Cangelosi G: Mutational analysis of cell wall biosynthesis in Mycobacterium avium. J Bacteriol 2003, 185:5003-5006

20. Meylan PR, Richman DD, Kornbluth RS: Characterization and growth in human macrophages of Mycobacterium avium complex strains isolated from the blood of patients with acquired immunodeficiency syndrome. Infect Immun 1990, 58:2564-2568.

21. Torrelles JB, Ellis D, Osborne T, Hoefer A, Orme IM, Chatterjee D, Brennan PJ, Cooper AM: Characterization of virulence, colony morphotype and the glycopeptidolipid of Mycobacterium avium strain 104. Tuberculosis 2002, 82:293-300.

22. Schorey JS, Sweet L: The mycobacterial glycopeptidolipids: Structure, function, and their role in pathogenesis. Glycobiology 2008, 18:832-841.

23. Philalay JS, Palermo CO, Hauge KA, Rustad TR, Cangelosi GA: Genes required for intrinsic multidrug resistance in Mycobacterium avium Antimicrob Agents Chemother 2004, 48:3412-3418.

24. Cangelosi GA, Do JS, Freeman R, Bennett JG, Semret M, Behr MA: The twocomponent regulatory system mtrAB is required for morphotypic multidrug resistance in Mycobacterium avium. Antimicrob Agents Chemother 2006, 50:461-468.

25. Freeman R, Geier H, Weigel KM, Do J, Ford TE, Cangelosi GA: Roles for cell wall glycopeptidolipid in surface adherence and planktonic dispersal of Mycobacterium avium. Appl Environ Microbiol 2006, 72:7554-7558.

26. Otero J, Jacobs WR Jr, Glickman MS: Efficient allelic exchange and transposon mutagenesis in Mycobacterium avium by specialized transduction. Appl Environ Microbiol 2003, 69:5039-5044.

27. Li Y, Miltner E, Wu M, Petrofsky M, Bermudez LE: A Mycobacterium avium PPE gene is associated with the ability of the bacterium to grow in macrophages and virulence in mice. Cell Microbiol 2005, 7:539-548.

28. Kalpana GV, Bloom BR, Jacobs WR Jr: Insertional mutagenesis and illegitimate recombination in mycobacteria. Proc Natl Acad Sci U S A 1991, 88:5433-5437.
29. Balasubramanian V, Pavelka MS Jr, Bardarov SS, Martin J, Weisbrod TR, McAdam RA, Bloom BR, Jacobs WR Jr: Allelic exchange in Mycobacterium tuberculosis with long linear recombination substrates. J Bacteriol 1996, 178:273-279.

30. Armitige LY, Jagannath $C$, Wanger $A R$, Norris $S$ : Disruption of the genes encoding antigen $85 \mathrm{~A}$ and antigen $85 \mathrm{~B}$ of Mycobacterium tuberculosis H37Rv: Effect on growth in culture and in macrophages. Infect Immun 2000, 68:767-778.

31. Bardarov S, Bardarov S Jr, Pavelka MS Jr, Sambandamurthy V, Larsen M, Tufariello J, Chan J, Hatfull G, Jacobs WR Jr: Specialized transduction: An efficient method for generating marked and unmarked targeted gene disruptions in Mycobacterium tuberculosis, M. bovis BCG and M. smegmatis. Microbiology 2002, 148:3007-3017.

32. Walochnik J, Obwaller A, Aspock H: Correlations between morphological, molecular biological, and physiological characteristics in clinical and nonclinical isolates of Acanthamoeba spp. Appl Environ Microbiol 2000, 66:4408-4413.

33. Visvesvara GS, Balamuth W: Comparative studies on related free-living and pathogenic amebae with special reference to Acanthamoeba. J Protozool 1975, 22:245-256.

34. Sambrook J: FE, Maniatis T: Molecular Cloning - A Laboratory Manual. 2nd edition. New York: Cold Spring Harbor Laboratory Press; 1989.

35. Sjobring $U$, Mecklenburg $M$, Andersen AB, Miorner $\mathrm{H}$ : Polymerase chain reaction for detection of Mycobacterium tuberculosis. J Clin Microbiol 1990, 28:2200-2204.

36. Krzywinska E, Schorey JS: Characterization of genetic differences between Mycobacterium avium subsp. avium strains of diverse virulence with a focus on the glycopeptidolipid biosynthesis cluster. Vet Microbiol 2003, 91:249-264.

37. Steinhauer K, Eschenbacher I, Radischat N, Detsch C, Niederweis M, GoroncyBermes P: Rapid evaluation of the Mycobactericidal efficacy of disinfectants in the quantitative carrier test EN 14563 by using fluorescent Mycobacterium terrae. Appl Environ Microbiol 2010, 76:546-554

38. Stover CK, De La Cruz VF, Fuerst TR, Burlein JE, Benson LA, Bennett LT, Bansal GP, Young JF, Lee MH, Hatfull GF, et al: New use of BCG for recombinant vaccines. Nature 1991, 351:456-460.

39. Hanahan D: Studies on transformation of Escherichia coli with plasmids. J Mol Biol 1983, 166:557-580.

40. Albers U, Reus K, Shuman HA, Hilbi H: The amoebae plate test implicates a paralogue of IpxB in the interaction of Legionella pneumophila with Acanthamoeba castellanii. Microbiology 2005, 151:167-182.

41. Lewin A, Freytag B, Meister B, Sharbati-Tehrani S, Schäfer H, Appel B: Use of a Quantitative TaqMan-PCR for the Fast Quantification of Mycobacteria in Broth Culture, Eukaryotic Cell Culture and Tissue. Journal of Veterinary Medicine Series B: Infectious Diseases and Veterinary Public Health 2003, 50:505-509.

42. Sharbati J, Lewin A, Kutz-Lohroff B, Kamal E, Einspanier R, Sharbati S: Integrated microRNA-mRNA-analysis of human monocyte derived macrophages upon Mycobacterium avium subsp. hominissuis infection. PLoS One 2011, 6:e20258.

43. Lee SH, Cheung M, Irani V, Carroll JD, Inamine JM, Howe WR, Maslow JN: Optimization of electroporation conditions for Mycobacterium avium. Tuberculosis 2002, 82:167-174

44. Horan KL, Freeman R, Weigel K, Semret M, Pfaller S, Covert TC, Van Soolingen D, Leão SC, Behr MA, Cangelosi GA: Isolation of the genome sequence strain Mycobacterium avium 104 from multiple patients over a 17-year period. J Clin Microbiol 2006, 44:783-789.

45. Niranjala Muttucumaru DG, Parish T: The molecular biology of recombination in Mycobacteria: What do we know and how can we use it? Current Issues in Molecular Biology 2004, 6:145-158.

46. Garbe TR, Barathi J, Barnini S, Zhang Y, Abou-Zeid C, Tang D, Mukherjee R, Young DB: Transformation of mycobacterial species using hygromycin resistance as selectable marker. Microbiology 1994, 140:133-138.

47. Scandurra GM, Young M, de Lisle GW, Collins DM: A bovine macrophage screening system for identifying attenuated transposon mutants of Mycobacterium avium subsp. paratuberculosis with vaccine potential. J Microbiol Methods 2009, 77:58-62.

48. Cavaignac SM, White SJ, De Lisle GW, Collins DM: Construction and screening of Mycobacterium paratuberculosis insertional mutant libraries. Arch Microbiol 2000, 173:229-231.

49. Collins DM, Wilson T, Campbell S, Buddle BM, Wards BJ, Hotter G, de Lisle GW: Production of avirulent mutants of Mycobacterium bovis with 
vaccine properties by the use of illegitimate recombination and screening of stationary-phase cultures. Microbiology 2002, 148:3019-3027.

50. Mukherjee S, Petrofsky M, Yaraei K, Bermudez LE, Cangelosi GA: The white morphotype of Mycobacterium avium-intracellulare is common in infected humans and virulent in infection models. J Infect Dis 2001, 184:1480-1484.

51. Cangelosi GA, Palermo CO, Bermudez LE: Phenotypic consequences of red-white colony type variation in Mycobacterium avium. Microbiology 2001, 147:527-533

52. Belisle JT, Brennan PJ: Chemical basis of rough and smooth variation in mycobacteria. J Bacteriol 1989, 171:3465-3470.

53. Collins FM, Cunningham DS: Systemic Mycobacterium kansasii infection and regulation of the alloantigenic response. Infect Immun 1981, 32:614-624.

54. Parrish NM, Ko CG, Dick JD, Jones PB, Ellingson JL: Growth, Congo Red agar colony morphotypes and antibiotic susceptibility testing of Mycobacterium avium subspecies paratuberculosis. Clin Med Res 2004, 2:107-114.

55. Deshayes C, Laval F, Montrozier H, Daffé M, Etienne G, Reyrat JM: A glycosyltransferase involved in biosynthesis of triglycosylated glycopeptidolipids in Mycobacterium smegmatis: Impact on surface properties. J Bacteriol 2005, 187:7283-7291.

56. Cangelosi GA, Palermo CO, Laurent JP, Hamlin AM, Brabant WH: Colony morphotypes on Congo red agar segregate along species and drug susceptibility lines in the Mycobacterium avium-intracellulare complex. Microbiology 1999, 145:1317-1324.

57. Shiratsuchi H, Toossi Z, Mettler MA, Ellner JJ: Colonial morphotype as a determinant of cytokine expression by human monocytes infected with Mycobacterium avium. J Immunol 1993, 150:2945-2954.

58. Curto M, Reali C, Palmieri G, Scintu F, Schivo ML, Sogos V, Marcialis MA, Ennas MG, Schwarz H, Pozzi G, et al: Inhibition of cytokines expression in human microglia infected by virulent and non-virulent mycobacteria. Neurochem Int 2004, 44:381-392.

59. Schaible UE, Sturgill-Koszycki S, Schlesinger PH, Russell DG: Cytokine activation leads to acidification and increases maturation of Mycobacterium avium-containing phagosomes in murine macrophages. J Immunol 1998, 160:1290-1296.

60. Steinert M, Birkness K, White E, Fields B, Quinn F: Mycobacterium avium bacilli grow saprozoically in coculture with Acanthamoeba polyphaga and survive within cyst walls. App/ Environ Microbiol 1998, 64:2256-2261.

61. Adékambi T, Salah SB, Khlif M, Raoult D, Drancourt M: Survival of environmental mycobacteria in Acanthamoeba polyphaga. Appl Environ Microbiol 2006, 72:5974-5981.

62. Cirillo JD, Falkow S, Tompkins LS, Bermudez LE: Interaction of Mycobacterium avium with environmental amoebae enhances virulence. Infect Immun 1997, 65:3759-3767.

63. Harriff M, Bermudez LE: Environmental amoebae and mycobacterial pathogenesis. Methods in molecular biology (Clifton, NJ) 2009, 465:433-442.

64. Danelishvili L, Wu M, Stang B, Harriff M, Cirillo S, Cirillo J, Bildfell R, Arbogast B, Bermudez LE: Identification of Mycobacterium avium pathogenicity island important for macrophage and amoeba infection. Proc Natl Acad Sci U S A 2007, 104:11038-11043.

65. Tenant R, Bermudez LE: Mycobacterium avium genes upregulated upon infection of Acanthamoeba castellanii demonstrate a common response to the intracellular environment. Curr Microbiol 2006, 52:128-133.

66. Goy G, Thomas $V$, Rimann K, Jaton K, Prod'hom G, Greub G: The Neff strain of Acanthamoeba castellanii, a tool for testing the virulence of Mycobacterium kansasii. Res Microbiol 2007, 158:393-397.

67. De Waal Malefyt R, Abrams J, Bennett B, Figdor CG, De Vries JE: Interleukin 10 (IL-10) inhibits cytokine synthesis by human monocytes: An autoregulatory role of IL-10 produced by monocytes. Journal of Experimental Medicine 1991, 174:1209-1220.

68. Cyktor JC, Turner J: Interleukin-10 and immunity against prokaryotic and eukaryotic intracellular pathogens. Infect Immun 2011, 79:2964-2973.

69. Smith I: Mycobacterium tuberculosis pathogenesis and molecular determinants of virulence. Clin Microbiol Rev 2003, 16:463-496.

70. Tateishi $Y$, Hirayama Y, Ozeki Y, Nishiuchi Y, Yoshimura M, Kang J, Shibata A, Hirata K, Kitada S, Maekura R, et al: Virulence of Mycobacterium avium complex strains isolated from immunocompetent patients. Microb Pathog 2009, 46:6-12

71. Stokes RW, Doxsee D: The receptor-mediated uptake, survival, replication, and drug sensitivity of Mycobacterium tuberculosis within the macrophage-like cell line THP-1: A comparison with human monocytederived macrophages. Cell Immunol 1999, 197:1-9.

72. Liu K, Yu J, Russell DG: pckA-deficient Mycobacterium bovis BCG shows attenuated virulence in mice and in macrophages. Microbiology 2003, 149:1829-1835.

73. Marrero J, Rhee KY, Schnappinger D, Pethe K, Ehrt S: Gluconeogenic carbon flow of tricarboxylic acid cycle intermediates is critical for Mycobacterium tuberculosis to establish and maintain infection. Proc Natl Acad Sci U S A 2010, 107:9819-9824.

74. Meena LS, Chopra P, Bedwal RS, Singh Y: Cloning and characterization of GTP-binding proteins of Mycobacterium tuberculosis H37Rv. Enzym Microb Technol 2008, 42:138-144.

75. Bijlsma JJE, Lie-A-Ling M, Nootenboom IC, Vandenbroucke-Grauls CMJE, Kusters JG: Identification of loci essential for the growth of Helicobacter pylori under acidic conditions. J Infect Dis 2000, 182:1566-1569.

76. Maloney E, Stankowska D, Zhang J, Fol M, Cheng QJ, Lun S, Bishai WR, Rajagopalan M, Chatterjee D, Madiraju MV: The two-domain LysX protein of Mycobacterium tuberculosis is required for production of lysinylated phosphatidylglycerol and resistance to cationic antimicrobial peptides. PLoS Pathogens 2009, 5:e1000534.

doi:10.1186/1471-2180-12-204

Cite this article as: Khattak et al:: Illegitimate recombination: An efficient method for random mutagenesis in Mycobacterium avium subsp. hominissuis. BMC Microbiology 2012 12:204.

\section{Submit your next manuscript to BioMed Central and take full advantage of:}

- Convenient online submission

- Thorough peer review

- No space constraints or color figure charges

- Immediate publication on acceptance

- Inclusion in PubMed, CAS, Scopus and Google Scholar

- Research which is freely available for redistribution

Submit your manuscript at www.biomedcentral.com/submit
C) BioMed Central 